\title{
PROGRAM PEMBERDAYAAN MASYARAKAT MELALUI PELATIHAN PENANGANAN KORBAN TENGGELAM
}

\author{
Hendy Lesmana ${ }^{1^{*}}$, Dewy Haryanti Parman ${ }^{2}$, Alfiaanur $^{3}$, Darni $^{4}$ \\ ${ }^{1}$ Departemen Keperawatan Kritis dan Gawat Darurat, Universitas Borneo Tarakan, Indonesia \\ 2,3,4 Jurusan Keperawatan, Fakultas Ilmu Kesehatan, Universitas Borneo Tarakan, Indonesia \\ ${ }^{1}$ hendylesmana2@gmail.com, ${ }^{2}$ dewyanmarsya79@gmail.com, ${ }^{3}$ alfianoer@gmail.com, \\ darni.resky86@gmail.com.
}

\begin{abstract}
ABSTRAK
Abstrak: Indonesia merupakan negara kepulauan dengan jumlah 13.466 pulau, demukian pula dengan Kota Tarakan yang merupakan daerah kepulauan dengan luas laut $\left(406,53 \mathrm{Km}^{2}\right)$ lebih besar dari daerah daratan $\left(250,80 \mathrm{Km}^{2}\right)$. Tenggelam merupakan kondisi kegawatdaruratan yang harus segera mendapatkan pertolongan, bila terlambat mendapatkan pertolongan maka akan menyebabkan kematian. Pada umumnya masyarakat adalah orang pertama yang menemukan korban sehingga peran masyarakat awam dalam melakukan pertolongan korban tenggelam secara cepat dan tepat sangat dibutuhkan guna meningkatkan angka harapan hidup korban tenggelam. Kegiatan pengabdian ini dilakukan dengan tahapan sosialisasi, simulasi dan evaluasi dari peserta pelatihan. Kegiatan dilakukan pada masyarakat yang ada di Kelurahan Pantai Amal yang merupakan msayarakat yang berada di daerah pesisir. Hasil pengabdian dimana terjadi peningkatan pengetahuan dan keterampilan masyarakat dalam melakukan pertolongan pertama kepada korban tenggelam, mulai dari penanganan korban tenggelam selama di laut maupun korban yang telah dilakukan evakuasi ke daratan.
\end{abstract}

Kata Kunci: Masyarakat Pesisir, Penanganan Korban Tenggelam, Pengetahuan dan Keterampilan Masyarakat.

\begin{abstract}
Indonesia is an archipelago country with a total of 13,466 islands, so also with the City of Tarakan which is an archipelago with a sea area (406.53 Km2) larger than the mainland area (250.80Km2). Drowning is an emergency condition that must immediately get help, if it's too late to get help it will cause death. In general, the community is the first person to find victims so that the role of ordinary people in assisting victims of drowning quickly and precisely is needed to increase the life expectancy of drowning victims. This dedication activity is carried out with the stages of socialization, simulation and evaluation of the training participants. The activity was carried out on the community in the Pantai Amal Village which is a community in the coastal area. The results of dedication where there is an increase in knowledge and skills of the community in conducting first aid to the victims of drowning, ranging from handling victims of drowning while at sea as well as victims who have been evacuated to the mainland.
\end{abstract}

Keywords: Coastal Communities, Management of Drowning Victims, Community Knowledge and Skills. 


\section{A. LATAR BELAKANG}

Indonesia merupakan daerah kepulauan dengan garis pantai yang cukup panjang, dimana jumlah pulau yang dimiliki adalah 13.466 pulau (Leatemia, 2011), (Lasabuda, 2013). Mayoritas masyarakat yang bermukim di daerah kepulauan khususnya didaerah pesisir pantai tersebut berprofesi sebagai nelayan. Masyarakat yang bermukin di daerah pesisir pantai dengan mata pencarian sebagai nelayan berisiko terjadinya kasus tenggelam yang dapat berujung pada kematian jika terlambat melakukan pertolongan (Mustafa \& Yudhicara, 2016). Tentu saja tidak ada seorangpun yang berharap kejadian (tenggelam) tersebut terjadi pada siapapun khususnya pada masyarakat yang tinggal didaerah pesisir pantai. Tenggelam merupakan penyebab kematian ke empat akibat kecelakaan umum (Syafi'i \& Chayati, 2016). Di Amerika Serikat dalam sepuluh tahun terakhir, lebih dari 50.000 penderita meninggal akibat tenggelam dan diperkirakan lebih dari 500.000 kejadian tenggelam setiap tahunnya.

Di Indonesia walaupun angka kejadian tenggelam tidak diketahui secara pasti, tetapi berdasarkan kondisi geografis wilayah Indonesia yang terdiri dari 13.466 pulau dan memiliki garis pantai yang cukup panjang memungkinkan kasus tenggelam lebih banyak dibandingkan negara dengan luas laut yang lebih kecil (Lasabuda, 2013), (Siti Fitriana \& Ismah, 2016).

Kota Tarakan merupakan salah satu pulau yang dikelilingi oleh laut dimana luas wilayah daratan $250.80 \mathrm{~km}^{2}$, luas wilayah laut $406,53 \mathrm{~km}^{2}$ dengan total jumlah luas wilayah $657,33 \mathrm{~km}^{2}$. Batas wilayah Kota Tarakan terdiri dari batas utara kota tarakan merupakan Pesisir pantai Kecamatan Pulau Bunyu Kabupaten Bulungan, batas timur merupakan Kecamatan Pulau Bunyu Kabupaten Bulungan dan Laut Sulawesi, batas selatan Pesisir Pantai Kecamatan Tanjung Palas Kabupaten Bulungan dan batas barat merupakan Pesisir Pantai Kecamatan Sesayap Kabupaten Tana Tidung (BPS Kota Tarakan, 2014). Kelurahan pantai amal merupakan salah satu kelurahan yang mayoritas penduduknya berada di pesisir pantai dan berprofesi sebagai nelayan serta petani rumput laut, sehingga keseharian dari masyarakat melakukan kontak dengan laut dan merupakan masyarakat yang memiliki angka kemungkinan kejadian tenggelam lebih tinggi (Koddeng, 2011). Kelurahan pantai amal merupakan kelurahan yang terdapat di kecamatan Tarakan Timur dengan luas wilayah $12.15 \mathrm{~km}^{2}$ dan jumlah penduduk sekitar 4.469 jiwa dimana pada umumnya penduduk berprofesi sebagai nelayan dan petani rumput laut. Masyarakat pesisir pantai di Kelurahan Pantai amal belum mendapatkan pelatihan dan workshop tentang penanganan pertama penderita tenggelam, bila mendapatkan penderita dengan tenggelam masyarakat sekitar hanya menggunakan pengalaman yang ada sehingga pertolongan yang diberikan tidak tepat dan dapat menyebabkan penderita meninggal atau cacat. 
Rendahnya tingkat pendidikan masyarakat dan kurangnya pengetahuan masyarakat tentang pertolongan pertama pada korban tenggelam, mendorong penulis untuk melakukan pengabdian kepada masyarakat di pesisir pantai Kelurahan Pantai Amal dengan tema "Program pemberdayaan masyarakat melalui pelatihan penanganan korban tenggelam pada masyarakat pesisir pantai di Kelurahan Pantai Amal Kota Tarakan".

\section{B. METODE PELAKSANAAN}

Tujuan dari kegiatan ini adalah meningkatkan pengetahuan tentang pentingnya penanganan pertama korban tenggelam pada masyarakat pesisir kelurahan pantai amal kota tarakan. Serta memberikan penjelasan tentang berbagai metode yang dapat dipakai atau digunakan dalam pelatihan tersebut. Untuk mencapai tujuan di atas, maka dilakukan beberapa tahap kegiatan sebagai berikut;

\section{Tahap Sosialisasi}

Memberikan pelatihan kepada masyarakat tentang penanganan pertama pada korban tenggelamdi daerah pesisir Kelurahan Pantai Amal Kota Tarakan.

\section{Tahap Simulasi}

Mempraktekkan cara penanganan pertama korban tenggelam pada masyarakat pesisir Kelurahan Pantai Amal Kota Tarakan.

\section{Tahap Evaluasi}

Evaluasi dilakukan untuk mengetahui sampai sejauh mana kegiatan yang dilaksanakan yang terkait dengan ketepatan pelaksanaan kegiatan dengan tujuan yang. Evaluasi kegiatan dibagi menjadi 2 (dua) bagian berdasarkan pelaksanaan kegiatan sesuai Tabel 1 berikut.

Tabel 1. Rancangan Evaluasi Kegiatan

\begin{tabular}{|c|c|c|c|c|}
\hline $\begin{array}{c}\text { Parameter } \\
\text { yang di } \\
\text { evaluasi }\end{array}$ & $\begin{array}{l}\text { Kriteria } \\
\text { Evaluasi }\end{array}$ & $\begin{array}{c}\text { Indikator } \\
\text { Pencapai } \\
\text { Tujuan }\end{array}$ & $\begin{array}{c}\text { Tolak ukur } \\
\text { keberhasilan }\end{array}$ & $\begin{array}{c}\text { Cara } \\
\text { mengukur } \\
\text { Indikator }\end{array}$ \\
\hline Sosialisasi & $\begin{array}{l}\text { Kesuksesan } \\
\text { Sosialisasi }\end{array}$ & $\begin{array}{l}\text { Memahami } \\
\text { kegiatan yang } \\
\text { akan } \\
\text { dilakukan }\end{array}$ & $\begin{array}{l}\text { Mampu } \\
\text { Meningkatkan } \\
\text { Pengetahun } \\
\text { tentang } \\
\text { penanganan } \\
\text { pertama pada } \\
\text { tenggelam di } \\
\text { kelurahan amal } \\
\text { Kota Tarakan }\end{array}$ & $\begin{array}{l}\text { Menggunakan } \\
\text { Kuisioner }\end{array}$ \\
\hline Simulasi & $\begin{array}{l}\text { Keberjhasilan } \\
\text { Pelatihan }\end{array}$ & $\begin{array}{l}\text { Penguasaan } \\
\text { Penanganan } \\
\text { dalam } \\
\text { simulasi }\end{array}$ & $\begin{array}{l}\text { Dapat } \\
\text { mempraktekkan } \\
\text { dalam simulasi } \\
\text { pengetahuan } \\
\text { yang didapat } \\
\text { pada tahap I }\end{array}$ & $\begin{array}{l}\text { From } \\
\text { penilaian } \\
\text { praktek }\end{array}$ \\
\hline
\end{tabular}




\section{HASIL DAN PEMBAHASAN \\ 1. Tahap Sosialisasi}

Pada pelaksanaan pengabdian yang kami lakukan, sebelumnya kami telah mendata kebutuhan dan keluhan dari masyarakat. Pada saat pemaparan, dari berbagai permasalahan yang sering terjadi melanda masyarakat adalah terkait dengan penanganan pertama pada masyarakat yang tenggelam. Di Indonesia walaupun angka kejadian tenggelam tidak diketahui secara pasti, tetapi berdasarkan kondisi geografis wilayah Indonesia yang terdiri dari 13.466 pulau dan memiliki garis pantai yang cukup panjang memungkinkan kasus tenggelam lebih banyak dibandingkan negara dengan luas laut yang lebih kecil.

Sebelum kegiatan pelatihan ini berlangsung, sebelumnya kami menjelaskan tujuan dari kegiatan pengabdian ini dan peran masyarakat dalam penanganan awal korban tenggelam sebelum petugas kesehatan tiba di lokasi kejadian.

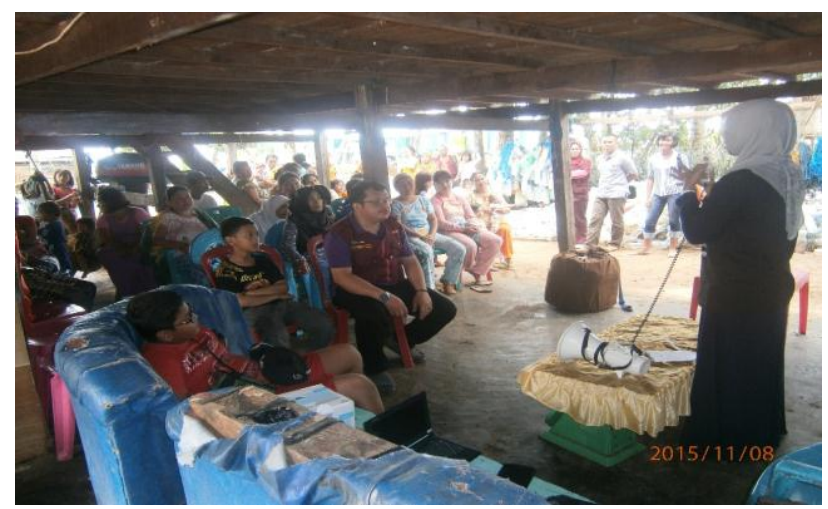

Gambar 1. Sosialisasi kepada masyarakat mengenai tujuan, manfaat serta peran masyarakat dalam penanganan korban tenggelam

\section{Tahap Simulasi}

Pada saat pelaksanaan pengabdian ini dimulai, peserta yang hadir sekitar 46 orang yang terdiri dari 29 orang perempuan dan 17 orang laki- laki. Pelaksanaan kegiatan ini bertepatan dengan waktu para nelayanan pergi melaut menyebabkan jumlah peserta perempuan lebih banyak dibandingkan laki-laki. Selama pelaksanaan kegiatan ini banyak informasi atau materi yang diberikan tentang bagaimana melakukan evakuasi dan pertolongan pada korban tenggelam. Saat pelaksaanan peserta terlihat sangat antusias saat mendengarkan.

Tahap simulasi diuraikan dari tahapan;

a. Analisis diri dan mengaktifkan emergency call

b. Menyelamatkan korban dari air

c. Tehnik pemberian nafas bantuan dengan alat

d. Kompresi dada

e. Penanganan muntah saat resusitasi

f. Menghangatkan korban 
g. Transportasi dan tehnik merujuk korban ke fasilitas kesehatan terdekat

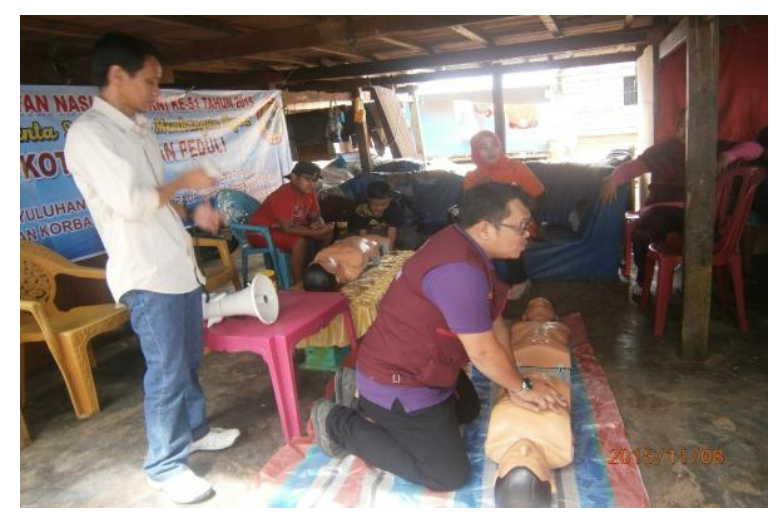

Gambar 2. Simulasi Resusitasi Jantung Paru

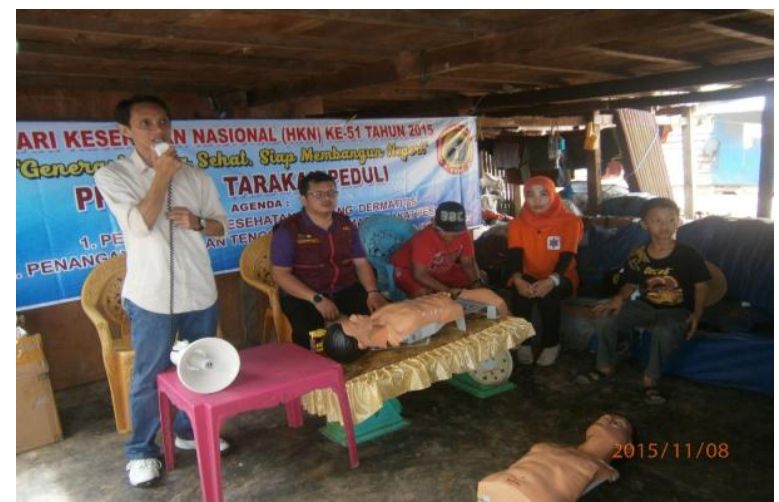

Gambar 3. Tim memberikan materi penanganan korban tenggelam

\section{Tahap Evaluasi}

Pengetahuan masyarakat selama ini penanganan pertama korban tenggelam pada masyarakat pesisir kelurahan pantai amal Kota Tarakan sangat kurang, terbukti disaat pengisian kuisoner lebih banyak yang tidak tau mengisi daripada yang isi secara benar. Setelah dilakukan pelatihan tentang hal tersebut masyarakat yang tidak mengetahui tentang penanganan pasien tenggelam menjadi lebih memahami tentang bagaimana penanganan pertolongan pertamama pada masyarakat atau korban tenggelam.



Gambar 3. Peserta pelatihan penenganan korban tenggelam 
Tabel 2. Rekapitulasi Pengetahuan Peserta Tentang Cara Penanganan Awal Korban Tenggelam.

\begin{tabular}{clcc}
\hline No & Penanganan & Pre-Test & Post-Test \\
\hline 1 & Benar & 23 & 40 \\
\hline 2 & Salah & 23 & 6 \\
\hline
\end{tabular}

Pada Tabel 2 menggambarkan bagaimana peningkatan pengetahuan peserta mengenai penanganan awal korban tengelam dimana saat pre-test hanya 23 peserta yang menjawab dengan benar 23 dan yang menjawab salah sedangkan saat post-test didapat 40 peserta mampu menjawab benar dan 6 peserta menjawab dengan salah. Setelah mengikuti pelatihan penanganan pada masyarakat tenggelam dapat mengetahui cara penanganan awal pada pasien tenggelam seperti menilai kesadaran pasien dengan menggoyang tubuh atau memanggil nama pasien. Jika korban masi bisa menjawab pertanyaan yang diberikan berarti masi bisa untuk ditolong saat itu, tetapi jika tidak ada respon sama sekali segera lakukan pemeriksaan selanjutnya.

Tabel 3. Rekapitulasi Pemahaman Peserta Mengenai Tindakan yang Tidak Perlu Dilakukan Pada Korban Tenggelam

\begin{tabular}{cccc}
\hline No & Penanganan / Kecuali & Pre-Test & Post-Test \\
\hline 1. & Benar & 28 & 36 \\
\hline 2. & Salah & 18 & 10 \\
\hline
\end{tabular}

Tabel 3 memperlihatkan bagaimana peningkatan pengetahuan peserta mengenai penanganan awal yang tidak perlu dilakukan pada korban tenggelam dimana saat pre-test hanya 28 yang menjawab dengan benar, 18 peserta yang menjawab salah sedangkan saat post-test peserta mampu menjawab pertanyaan dengan benar 36 , sisanya 10 yang menjawab salah. Setelah mendapatkan pelatihan penanganan pertama pada korban tenggelam masyarakat suda dapat memahami dan mengerti cara penangan tenggelam jika terjadi, dimana cara tersebut adalah kombunasi napas bantuan dan kompresi dada/resusitasi jantung paru (RJP), segera menilai segala sesuatu yang dapat membahanyakan pasien dan penolong itu sendiri, dan menilai kesadaran pasien dengan $m$ enggoyang tubuh pasien atau memanggil namanya.dengan cara ini bisa menyelamatkan korban yang tenggelam sebelum tim kesehatan memberikan pertolongan.

Tabel 4. Rekapitulasi Pengetahuan Peserta Mengenai Tindakan RJP Pada Korban Tenggelam.

\begin{tabular}{rlcc}
\hline No & Penanganan & Pre-Test & Post-Test \\
\hline 1. & Benar & 27 & 39 \\
\hline 2. & Sadar & 19 & 7 \\
\hline
\end{tabular}

Tabel 4. menggambarkan bagaimana peningkatan pengetahuan peserta mengenai cara RJP dengan mengetahuai tindakan yang bukan termasuk RJP dimana saat pre-test hanya 27 yang menjawab dengan benar, 19 peserta yang menjawab salah sedangkan saat post-test peserta mampu menjawab dengan 
benar 39 peserta dan 7 yang menjawab salah. Setelah mendapatkan pelatihan penanganan pertama pada korban tenggelam masyarakat suda dapat memahami dan mengerti cara melakukan RJP.

Tabel 5. Rekapitulasi Pengetahuan Peserta Mengenai Akibat

Kejadian Tenggelam

\begin{tabular}{rlcc}
\hline No & Penanganan & Pre-Test & Post-Test \\
\hline 1. & Benar & 15 & 42 \\
\hline 2. & Sadar & 31 & 4 \\
\hline
\end{tabular}

Tabel 5 menggambarkan bagaimana peningkatan pengetahuan peserta mengenai efek atau akibat dari kejadian tenggelam dimana saat pre-test hanya 15 peserta yang menjawab dengan benar, 31 peserta yang menjawab salah sedangkan saat post-test peserta mampu menjawab dengan benar 42 dan 4 peserta menjawab salah. Setelah mendapatkan pelatihan penanganan pertama pada korban tenggelam masyarakat suda dapat memahami dan mengerti tentang efek atau akibat dari tenggelam seperti pasien yang tidak stabil akan koma dan akan lebih buruk, jika hal tersebut terjadi maka segera mungkin hubungi pihak kesehatan / medis untuk penanganna awal secepatnya.

Tabel 6. Rekapitulasi Pengetahuan Peserta Mengenai Penyelamatan Korban di Air

\begin{tabular}{clcc}
\hline No & Penanganan & Pre-Test & Post-Test \\
\hline 1. & Benar & 37 & 43 \\
\hline 2. & Sadar & 19 & 3 \\
\hline
\end{tabular}

Tabel 6 menggambarkan bagaimana peningkatan pengetahuan peserta mengenai cara menyelamatkan korban dari dalam air, dimana saat pre-test hanya 37 peserta yang menjawab dengan benar dan 19 peserta yang menjawab salah sedangkan saat post-test peserta mampu menjawab dengan benar 43 dan hanya 3 peserta yang menjawab salah. Setelah melakukan pelatihan penanganan pertama pada masyarakat tenggelam masyarakat setempat bisa mengetahui dan memahami cara menyelamatkan korban dari dalam air, dimana cara penanganannya penolong harus dapat mencapai korban secepat mungkin dan menggunakan alat angkat untuk membawa korban ke darat untuk mendapatkan pertolongan secepatnya.

\begin{tabular}{|c|c|c|c|}
\hline No & Penanganan & Pre-Test & Post-Test \\
\hline 1. & Benar & 33 & 37 \\
\hline 2. & Sadar & 13 & 9 \\
\hline
\end{tabular}

Tabel 7. memperlihatkan bagaimana peningkatan pemahaman peserta mengenai pemberian napas bantuan kepada korban saat di dalam air. Saat pre-test ada 33 peserta menjawab dengan benar dan 13 peserta yang menjawab salah, sedangkan saat post-test peserta yang mampu menjawab 
dengan benar ada 37 dan hanya 9 peserta yang menjawab salah. Tindakan menolong orang tenggelam sifatnya harus secepat mungkin, seperti menolong pasien didalam air memberikan napas bantuan, bisa dilakukan bagi orang yang berpengalaman,dan bisa melakukannya didalam air, tetapi jika tidak memungkinkan sebaiknya dibawa kedarat dan diberikan bantuan.

Tabel 8. Rekapitulasi Pengetahuan Peserta Mengenai Langkah-Langkah

\begin{tabular}{clcc}
\multicolumn{4}{c}{ Pertolongan Pada Korban Tenggelam } \\
\hline No & Penanganan & Pre-Test & Post-Test \\
\hline 1. & Benar & 13 & 36 \\
\hline 2. & Salah & 33 & 10 \\
\hline
\end{tabular}

Tabel 8 menggambarkan bagaimana peningkatan pemahaman peserta mengenai langkah-langkah penanganan korban tengelam, dimana saat pre test hanya 13 peserta yang menjawab dengan benar dan 33 peserta yang menjawab salah, sedangkan saat post test terjadi peningkatan secara signifikan dimana peserta yang mampu menjawab dengan benar ada 36 peserta dan hanya 10 yang menjawab salah. Setelah melakukan pelatihan penanganan pada masyarakat tenggelam, cara penangannya ada beberapa seperti kompresi dada, cara melakukan kompresi dada yaitu membuka jalan napas, mengecek pernapasan, memberikan dua kali napas bantuan, kemudian harus mengecek denyut nadi korban kembali, tindakan inin dilakukan untuk memastikan jika korban masi hidup dan secepatnya dibantu.

Tabel 9. Rekapitulasi Pengetahuan Peserta Mengenai Penanganan Muntah Pada Korban Tenggelam

\begin{tabular}{rlcc}
\hline No & Penanganan & Pre-Test & Post-Test \\
\hline 1. & Benar & 11 & 40 \\
\hline 2. & Sadar & 35 & 6 \\
\hline
\end{tabular}

Tabel 9 menggambarkan bagaimana peningkatan pemahaman peserta mengenai penanganan muntah pada korban tenggelam dimana saat pre test hanya 11 peserta yang menjawab dengan benar dan 35 peserta yang menjawab salah, namun saat post test ada peningkatan yang signifikan dimana peserta mampu menjawab dengan benar ada 40 peserta,dan sisanya 6 peserta yang menjawab salah. Setelah mendapatkan pelatihan penanganan pada masyarakat tenggelam terdapat juga cara penanganan muntah yang benar, jika terjadi muntah segera kepala dimiringkan kesamping dan bersihkan muntah dengan jari, pakaian, atau penyedot sehingga sisa muntah tidak masuk kembali kedalam mulut dan menghalangi sistem pernapasan.

Tabel 10. Rekapitulasi Pengetahuan Peserta Mengenai Tindakan Yang Dilakukan Saat Pakaian Korban Basah

\begin{tabular}{clcc}
\hline No & Penanganan & Pre-Test & Post-Test \\
\hline 1. & Benar & 38 & 45 \\
\hline 2. & Sadar & 18 & 1 \\
\hline
\end{tabular}


Tabel 10 menggambarkan bagaimana peningkatan pengetahuan peserta mengenai tindakan yang dilakukan saat pakaian korban basah, dimana saat pre-test ada 38 peserta dapat menjawab dengan benar dan 18 peserta yang menjawab salah, sedangkan saat post-test ada 45 peserta mampu menjawab dengan benar dan hanya 1 yang menjawab salah.setelah kita mempelajari tentang penanganan tenggelam dan telah mengetahui cara-cara penangannya terutama jika pakaian yang basah secepat mungkin diganti dengan pakaian yang kering, sehungga masyarakt tidak mengalami kedinginan.

Tabel 11. Rekapitulasi Pemahaman Peserta Mengenai Tindakan Yang Harus Dilakukan Saat Korban Mengalami Komplikasi atau Cacat

\begin{tabular}{clcc}
\hline No & Penanganan & Pre-Test & Post-Test \\
\hline 1. & Benar & 41 & 45 \\
\hline 2. & Sadar & 5 & 1 \\
\hline
\end{tabular}

Tabel 11 menggambarkan bagaimana peningkatan pemahaman peserta mengenai tindakan yang harus dilakukan saat korban mengalami komplikasi atau cacat, dimana saat pre-test ada 41 peserta yang menjawab dengan benar dan 5 peserta yang menjawab salah sedangkan saat post-test peserta mampu menjawab dengan benar ada 45 dan hanya 1 yang menjawab salah. Setelah mendapatkan pelatihan tentang penanganan korban tenggelam dan terjadi komplikasi atau cacat diharapkan untuk membanya ke rumah sakit terdekat, supaya mendapatkan pertolongan lebih cepat.

\section{SIMPULAN DAN SARAN}

Pelaksanaan kegiatan pengabdian masyarakat dalam bentuk pelatihan penanganan korban tenggalam pada masyarakat pesisir terdiri dari 3 tahapan, yakni; 1) Tahap sosialisasi; dimana penulis menjelaskan tujuan, manfaat dan peran masyarakat dalam penanganan korban tenggelam, 2) tahap simulasi; dimana penulis melakukan demonstrasi bagaimana cara yang tepat dalam penanganan korban tenggelam yang dimulai dari penanganan korban di laut hingga penanganan korban yang telah di evakuasi didaratan, 3) Evaluasi; penulis telah melakukan pre-test dan post-test dalam kegiatan ini, dimana terlihat tingakt pengetahuan masyarakat pesisir dalam penanganan korban tenggelam sangat kurang terbukti banyak masyarakat menjawab salah pertanyaan pada kuesioner, tetapi setelah dilakukan simulasi terjadi peningkatan pengetahuan yang signifikan dimana masyarakat dapat menjawab dengan benar $>80 \%$ dari 10 pertanyaan yang terdapat dalam kuesioner.

Saran untuk memaksimalkan penanganan korban tenggelam sebaiknya dibentuk suatu perkumpulan masyarakat yang siap melakukan pertolongan pada korban tenggelam, sehingga bila terjadi kasus maka 
masyarakat dengan sigap dapat melakukan pertolongan dengan cepat dan tepat.

\section{UCAPAN TERIMA KASIH}

Kami ucapkan terima kasih tak terhingga kepada Rektor Universitas Borneo Tarakan dan Ketua Lembaga Penelitian dan Pengabdian Kepada Masyarakat (LPPM) atas kesempatan yang diberikan kepada kami untuk melaksanakan pengabdian kepada masyarakat. Kepada Dekan Fakultas

Ilmu Kesehatan (FIKES) dan ketua Jurusan Keperawatan Universitas Borneo atas supprot dan bantuan alat manikin RJP, BVM serta alat lainnya.

\section{DAFTAR RUJUKAN}

BPS Kota Tarakan. (2014). Kota Tarakan Dalam Angka 2014. Tarakan.

Koddeng, B. (2011). Zonasi Kawasan Pesisir Pantai Makassar Berbasis Mitigasi Bencana (Studi Kasus Pantai Barambong-Celebes Convention Centre). Prosiding 2011, 5(Group Teknik Arsitektur), TA17-1 - 14.

Lasabuda, R. (2013). Pembangunan Wilayah Pesisir Dan Lautan Dalam Perspektif Negara Kepulauan Republik Indonesia. Jurnal Ilmiah Platax, 1(2), 92. https://doi.org/10.35800/jip.1.2.2013.1251

Leatemia, J. (2011). Substansi Pengaturan Hukum Daerah Kepulauan. Jurnal $\begin{array}{llll}\text { Hukum } \quad \& \quad \text { Pembangunan, } & 41(2), & \end{array}$ https://doi.org/10.21143/jhp.vol41.no2.247

Mustafa, M. A., \& Yudhicara, Y. (2016). Karakteristik Pantai Dan Resiko Tsunami Di Kawasan Pantai Selatan Yogyakarta. Jurnal Geologi Kelautan, 5(3). https://doi.org/10.32693/jgk.5.3.2007.143

Siti Fitriana \& Ismah, M. R. (2016). Meningkatkan Penyesuaian Diri Mahasiswa Baru Melalui Layanan Informasi Dengan Teknik Modelling Simbolik. EProceeding of Management ISSN: 2355-9357, 3(1 April), 477-484. https://doi.org/10.1037/cou0000103.

Syafi'i, M., \& Chayati, C. (2016). Penanggulangan Abrasi Pantai di Desa Gersik Putih Kecamatan Gapura. Jurnal Ilmiah MITSU, 4(1). https://doi.org/10.24929/ft.v4i1.202 